\title{
Dampak Pertumbuhan Inklusi Keuangan terhadap Stabilitas Sistem Keuangan di Indonesia
}

\author{
Komang Agus Rudi Indra Laksmanaa, ${ }^{\mathrm{a}}$, Ngurah Arya Suryadhana ${ }^{\mathrm{b}}$ \\ abUniversitas Mahendradatta, Denpasar, Indonesia \\ email : ilaksmana70@gmail.com
}

\begin{abstract}
This study aimed at examining the effect of financial inclusion on the financial stability of banks in Indonesia. The data panel used in the study during the period 2007-2017 and were analyzed using multiple regression, financial inclusion variables using MSME credit growth indicators and GDP growth rates', while the dependent variable banking financial stability used the non-performing loan ratio (NPL) indicator. The results showed that MSME credit growth had a negative influence on credit risk which was associated with better stability. GDP growth rates had a positive and significant direct effect on financial stability (NPL) of banks in Indonesia. At the same time, it had a significant influence as a moderating variable on the relationship between financial inclusion and financial stability of banks in Indonesia.
\end{abstract}

Keywords: Financial inclusion, GDP, NPL

\section{PENDAHULUAN}

Inklusi keuangan atau sistem keuangan inklusif adalah sebuah sistem dimana Negara memiliki akses yang efektif ke berbagai produk dan layanan keuangan. Layanan keuangan dasar termasuk tabungan, kredit, pembayaran, asuransi, pengiriman uang dan investasi, untuk seluruh segmen pasar yang berbeda termasuk yang belum terlayani dan tidak terlayani. Inkluasi keuangan dapat diukur dengan proporsi individu dan perusahaan yang menggunakan jasa keuangan (World Bank, 2014). Akses mudah ke berbagai layanan keuangan bagi rumah tangga berpenghasilan rendah, rentan dan kategori kurang mampu, sesuai dengan kebutuhan mereka adalah tujuan dari inkluasi keuangan. Akses universal untuk membiayai merangsang kegiatan ekonomi dan memungkinkan usaha mikro, kecil dan menengah untuk berkembang, menghasilkan perluang dan penghasilan yang lebih tinggi dan lebih besar (Park dan Mecado, 2015).

Inklusi keuangan adalah konsep yang luas dan tidak ada metode standar yang dapat diukur. World Bank dan International Monetery Fund (IMF) menggunakan indikator yang berbeda untuk mengukur inklusi keuangan. Pada tahun 2012, G20 merilis G20 Basic Set Financial Inclusion Indicators yang mengukur dimensi akses, penggunaan dan kualitas. Ketiganya merupakan integrasi dari indikator yang digunakan IMF dan Bank Dunia. Akses adalah kemampuan untuk menggunakan jasa keuangan dan produk yeng tersedia dari lembaga formal, pengunaan berfokus pada kedalaman, keteraturan, frekuensi 
dan durasi penggunaan layanan keuangan dari waktu ke waktu. Selanjutnya kualitas mengacu pada relevansi layanan keuangan atau produk kepada konsumen. Ini mencakup pengalaman, sikap, dan pendapat mereka terhadap penyedia layanan keuangan dan layanan keuangan yang tersedia (Hanning dan Jansen, 2010).

Inkluasi keuangan dapat mengubah komposisi sistem keuangan dalam hal transaksi, layanan dan jalur akses yang tersedia untuk masyarakat. Perubahan-perubahan ini akan menciptakan potensi risiko baru atau guncangan yang cenderung menyebabkan ketidakstabilan keuangan seperti kegagalan kolektif lembaga yang lebih kecil yang dapat secara signifikan mempengaruhi stabilitas dalam sistem. Di sisi lain, inklusi keuangan dapat melawan ketidakstabilan dengan membuat sistem keuangan lebih terdibersifikasi (Hanning dan Jansen, 2010).

Menurut sebuah studi yang dilakukan oleh Asia Development Bank (ADB) di kawasan Asia-Pasifik yang memiliki populasi besar di wilayah ini masih bergantung pada layanan keuangan informal karena kurangnya akses ke lembaga formal. Populasi bervariasi di antara Negara-negara, tetapi diperkirakan bahwa sekitar $70 \%$ hingga $80 \%$ orang dewasa di wilayah ini tidak memilik akses ke sistem keuangan formal (Ayyagari dan Beck, 2015). Indonesia merupakan salah satu Negara yang memiliki penduduk terbesar di kawasan Asia, berdasarkan hasil survey dari Global Index 2017, sebanyak 48,9\% penduduk dewasa di Indonesia memiliki rekening simpanan di lembaga keuangan formal (bank umum, BPR, koperasi, lembaga keuangan mikro, uang elektronik terdaftar). Angka ini menunjukan peningkatan sebesar 12,8\% dibandingkan hasil survey tahun 2014, yaitu 36,1\%. Artinya pertumbuhan rekening simpanan per tahun mencapai kurang lebih 4,2\%. Dalam perbandingan global, pertumbuhan kepemilikan rekening simpanan di Indonesia tertinggi di Negara-negara di kawasan Asia Timur dan Pasifik. Di antara Negara-negara ASEAN, Indonesia menempati peringkat ke-4 dalam hal kepemilikan rekening simpanan. Namun secara umum, pencapaian inklusi keuangan di Indonesia sebesar $48,9 \%$ dengan 95.414 .559 penduduk dewasa. 


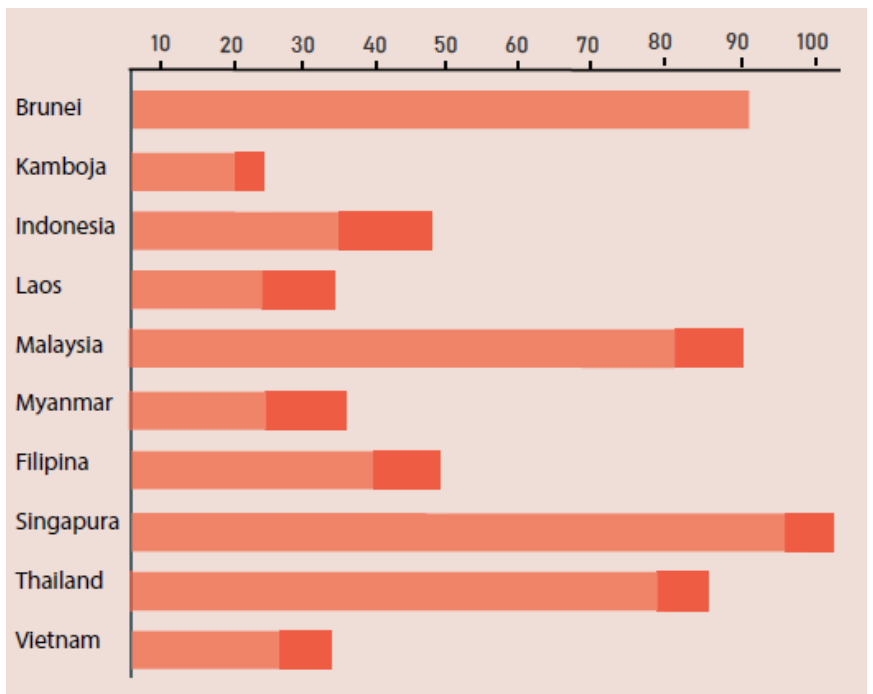

Gambar 1. Tingkat inkluasi keuangan Negara kawasan ASEAN 2017 Sumber: SNKI 2018

Di Indonesia, sistem keuangan masih didominasi oleh perbankan, pendalaman inklusi keuangan telah menjadi agenda nasional hal ini adalah platform untuk menyediakan kehidupan yang lebih baik bagi masyarakat Indonesia. Strategi dan kebijakan nasional semakin ditingkatkan dengan fokus pada bidang kebijakan, regulasi dan pengawasan, pendidikan keuangan dan perlindungan konsumen. Secara keseluruhan, tingkat inkluasi keuangan masih jauh dari Negara berkembang atau Negara tetangga ASEAN lainnya. Penelitian ini akan menggambarkan sejauh mana inklusi keuangan di Indonesia, dan menganalisis hubungan antara inklusi keuangan berkontribusi terhadap stabilitas system keuangan di Indonesia.

\section{TELAAH LITERATUR}

\section{Inkluasi Keuangan}

Menurut Global Partnership of Financial Inclusion (GPFI) dan G-20, inklusi keuangan telah menjadi komponen penting dari pengembangan keuangan, meningkatkan akses layanan keuangan bagi banyak masyarakat yang menjadi prioritas bagi pembuat kebijakan. The Global Financial Crisis (GFC) 2007-2008 menguji rasional inkluasi keuangan ketika kegagalan bank dikaitkan dengan inkluasi keuangan (Carneiro \& Ghosh, 2008). Inkluasi keuangan juga telah dikaitkan peningkatan kinerja keuangan (Allen et al., 2013). Terlepas dari semua kepentingan dan perhatian baru terhadap inkluasi keuangan dan klaim bahwa GFC diperepat oleh inklusi keuangan, masih ada kekurangan bukti empiris untuk membawa dampai ini pada kesimpulan.

Inkluasi keuangan dapat diukur menggunakan tiga dimensi yaitu, ketersediaan, aksesbilitas dan penggunaan. Dimensi ketersediaan digunakan untuk menjelaskan jangkauan sektor keuangan dalam hal 
outlet fisik bank, karena jarak fisik ke titik fisik layanan keuangan dianggap hambatan penting untuk inkluasi keuangan (Allen et a.,2013). Ketersediaan layanan perbankan diwakili dalam istilah penetrasi cabank bank, ATM dan Agen (Mostak \& Sushanta, 2015). Untuk aksesbilitas jumla tabungan, pinjaman dan akun ponsel per 1000 populasi dewasa digunakan untuk mengintegrasikan kedalaman akses keuangan. Dimensi penggunaan termasuk volume kredit ditambah deposito relative terhadap PDB (Beck, et al., 2013).

\section{Parameter Inklusi Keuangan}

Empat parameter di mana inkluasi keuangan dapat diukut adalah akses, penggunaan, kualitas dan kesejahteraan. Akses mengacu pada pasokan dan ketersediaan produk dan layanan keuangan. Penggunaan adalah pemanfaatan berbagai produk dan layanan oleh rumah tangga dan bisnis. Kualitas berkaitan dengan pengalaman konsumen dan persepsi relevansi suatu produk atau layanan.

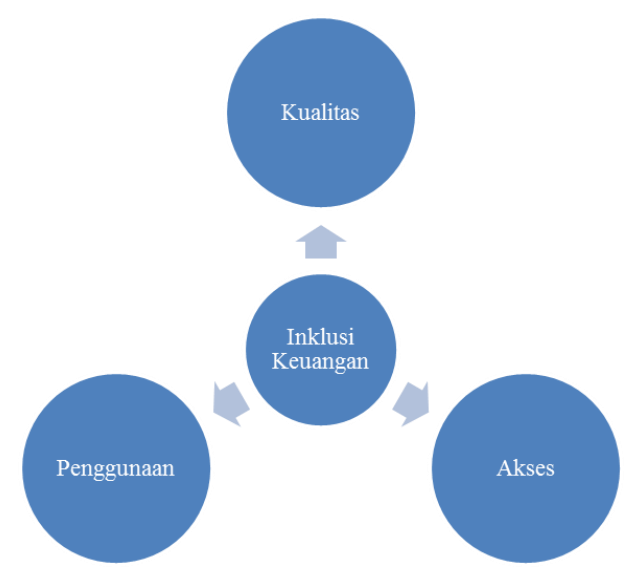

\section{Gambar 2. Paramater Inklusi Keuangan}

\section{Produk Domestik Bruto}

Berdasarkan press release Departemen Statistik Bank Indonesia menyatakan bahwa Produk Domestik Bruto (PDB) merupakan salah satu indikator penting untuk mengetahui perkembangan perekonomian di suatu negara dalam suatu periode tertentu, baik atas dasar harga berlaku maupun atas dasar harga konstan. PDB pada dasarnya merupakan jumlah nilai tambah yang dihasilkan oleh seluruh unit usaha di suatu negara tertentu dalam periode tertentu. Jumlah nilai barang dan jasa akhir yang disediakan dari produksi harus sama dengan nilai barang yang digunakan. PDB atas dasar harga berlaku menggambarkan nilai tambah barang dan jasa yang dihitung menggunakan harga yang berlaku pada 
setiap tahun, sedang PDB atas dasar harga konstan menunjukkan nilai tambah barang dan jasa tersebut yang dihitung menggunakan harga yang berlaku pada satu tahun tertentu sebagai tahun dasar. PDB menurut harga berlaku digunakan untuk mengetahui pergeseran, dan struktur ekonomi suatu negara. Sementara itu, PDB konstan digunakan untuk mengetahui kemampuan sumber daya dalam mendorong pertumbuhan ekonomi secara riil dari tahun ke tahun atau pertumbuhan ekonomi yang tidak dipengaruhi oleh faktor harga. PDB juga dapat digunakan untuk mengetahui perubahan harga dengan menghitung deflator PDB (perubahan indeks implisit). Indeks harga implisit merupakan rasio antara PDB menurut harga berlaku dan PDB menurut harga konstan.

Sumber data untuk PDB di Indonesia adalag Badan Pusat Statistik (BPS): Survei Khusus Triwulanan (SKT) institusi (lembaga) dan perusahaan, Survei Khusus Tabungan dan Investasi Rumah tangga (SKTIR), Sensus Ekonomi, Survei Sosial Ekonomi Nasional (Susenas), Sensus tahunan untuk perusahaan besar dan menengah, survei untuk perusahaan kecil, Anggaran Pendapatan dan Belanja Negara/APBN, survei adhoc dan data IHK \& IHPB. Data ekspor barang diperoleh dari publikasi tahunan BPS, sedangkan untuk ekspor jasa diperoleh dari neraca pembayaran yang dipublikasikan Bank Indonesia.

Selama ini, data PDB yang dipublikasikan oleh BPS menggunakan pendekatan produksi (lapangan usaha) dan pendekatan pengeluaran (penggunaan). Pengumpulan data PDB dilakukan sebagai berikut: Untuk PDB sektoral, data dikumpulkan dari departemen/intansi terkait. Data yang dikumpulkan dari setiap sektor antara lain berupa data produksi, data harga di tingkat produsen, dan biaya yang dikeluarkan untuk berproduksi, serta data pengeluaran, yang diperoleh baik melalui survei maupun estimasi. - Untuk PDB pengeluaran, data dikumpulkan departemen/intansi terkait yang secara resmi mengeluarkan data (seperti ekspor-impor, pengeluaran dan investasi pemerintah, serta investasi swasta) dan melalui survei-survei khusus (seperti survei khusus pengeluaran rumah tangga).

Dalam penelitian ini akan menggunakan PDB pengeluaran atas dasar harga berlaku karena menunjukkan produk barang dan jasa digunakan untuk tujuan konsumsi akhir, investasi dan diperdagangkan dengan pihak luar negeri selama periode tahun 2007-2017.

\section{Parameter Stabilitas Keuangan}

Stabilitas Sistem Keuangan (SSK) sebenarnya belum memiliki definisi baku yang telah diterima secara internasional. Oleh karena itu, muncul beberapa definisi mengenai SSK yang pada intinya mengatakan bahwa suatu sistem keuangan memasuki tahap tidak stabil pada saat sistem tersebut telah membahayakan dan menghambat kegiatan ekonomi. Di bawah ini dikutip beberapa definisi SSK yang diambil dari berbagai sumber. Sistem keuangan yang stabil mampu mengalokasikan 
sumber dana dan menyerap kejutan (shock) yang terjadi sehingga dapat mencegah gangguan terhadap kegiatan sektor riil dan sistem keuangan.

Sistem keuangan yang stabil adalah sistem keuangan yang kuat dan tahan terhadap berbagai gangguan ekonomi sehingga tetap mampu melakukan fungsi intermediasi, melaksanakan pembayaran dan menyebar risiko secara baik. Stabilitas sistem keuangan adalah suatu kondisi dimana mekanisme ekonomi dalam penetapan harga, alokasi dana dan pengelolaan risiko berfungsi secara baik dan mendukung pertumbuhan ekonomi.

Arti stabilitas sistem keuangan dapat dipahami dengan melakukan penelitian terhadap faktor-faktor yang dapat menyebabkan instabilitas di sektor keuangan. Ketidakstabilan sistem keuangan dapat dipicu oleh berbagai macam penyebab dan gejolak. Hal ini umumnya merupakan kombinasi antara kegagalan pasar, baik karena faktor struktural maupun perilaku. Kegagalan pasar itu sendiri dapat bersumber dari eksternal (internasional) dan internal (domestik). Risiko yang sering menyertai kegiatan dalam sistem keuangan antara lain risiko kredit, risiko likuiditas, risiko pasar dan risiko operasional.

Meningkatnya kecenderungan globalisasi sektor finansial yang didukung oleh perkembangan teknologi menyebabkan sistem keuangan menjadi semakin terintegrasi tanpa jeda waktu dan batas wilayah. Selain itu, inovasi produk keuangan semakin dinamis dan beragam dengan kompleksitas yang semakin tinggi. Berbagai perkembangan tersebut selain dapat mengakibatkan sumber-sumber pemicu ketidakstabilan sistem keuangan meningkat dan semakin beragam, juga dapat mengakibatkan semakin sulitnya mengatasi ketidakstabilan tersebut.

Identifikasi terhadap sumber ketidakstabilan sistem keuangan umumnya lebih bersifat forward looking (melihat kedepan). Hal ini dimaksudkan untuk mengetahui potensi risiko yang akan timbul serta akan mempengaruhi kondisi sistem keuangan mendatang. Atas dasar hasil identifikasi tersebut selanjutnya dilakukan analisis sampai seberapa jauh risiko berpotensi menjadi semakin membahayakan, meluas dan bersifat sistemik sehingga mampu melumpuhkan perekonomian (https://www.bi.go.id/id/perbankan/ssk/ikhtisar/definisi/Contents/Def ault.aspx)

Dalam penelitian ini akan menggunakan risiko kredit berupa non performing loan sebagai indikator stabilitas system keuangan di Indonesia selama periode tahun 2007-2017.

\section{Hubungan Inklusi Keuangan dan Stabilitas Keuangan}

\subsection{Penelitian Terdahulu}

Morgan dan Pontines (2014) memverfikasi hubungan antara inklusi keuangan dan stabilitas keuangan menggunakan pinjaman UKM sebagai ukuran inklusi keuangan dan rasio Non Performing Loan (NPL) sebagai ukuran stabilitas keuangan. Hasil penelitian menunjukan 
keduaanya saling menguatkan. Hasil estimasi mereka menunjukan bahwa peningkatan pangsa pinjaman kepada UKM dalam total pinjaman bank membantu stabilitas keuangan, terutama penurunan NPL.

Sebaliknya, laporan WGFD 2014 dari Bank Dunia menunjukan bahwa inklusi keuangan tidak memiliki hubungan yang signifikan dengan stabilitas keuangan. Penggunaan indikator penetrasi pinjaman dengan tingkat efisiensi di lembaga keuangan. Hasilnya tidak terdapat korelasi yang signifikan antara penetrasi pinjaman dan stabilitas keuangan. Demikian pula, data lintas Negara di pasar keuangan menunjukan bahwa sementara inkulasi keuangan dikaitkan secara positif dengan kedalaman dan efisiensi tidak memiliki hubungan yang signifikan dengan stabilitas.

Penelitian terkait keuangan mikro mengungkapkan bahwa kontribusi UKM terhadap pertumbuhan produktivitas di Negara Berkembang tidak setinggi perusahaan besar. Bukti penelitian yang dilakukan lintas Negara yakni hubungan antara UKM dan pertumbuhan ekonomi dan pengentasan kemiskinan menunjukan bahwa keberadaan sektor UKM yang besar tidak mendorong pertumbuhan produ domestic bruto per kapita (PDB) dan UKM tidak berdampak kausal pada pertumbuhan dan kemiskinan (Beck, Demirguc-Kunt, dan Levine, 2004).

Studi yang mengeksplorasi dampak keuangan mikro pada kewirausahaan menemukan efek yang relative sederhana. Banyak keterbatasan kredit mikro sebagai alat untuk membiayai kewirausahaan merupakan hasil dari ketidak fleksibelan kredit mikro, termasuk kurangnya tenggang waktu, pembayaran rutin, dan kewajiban bersama yang dapat mencegah tindakan risiko (Gine Jakiela, et.al.,2009).

Studi lainnya yang menganalisis inkulasi keuangan dan stabilitas keuangan di Filipina menunjukan bahwa peningkatan inklusi keuangan saat ini tidak meningkatkan stabilitas keuangan atau hasil dari ketidakstabilan keuangan. Tidak ditemukan bukti cukup untuk membuat kesimpulan pasti tentang hubungan antara inklusi keuangan dan stabilitas keuangan. Studi ini tidak menunjukan hubungan NPL dengan sejumlah lembaga fisik, pinjaman kepada UMKM, likuiditas dan GDP. Hal ini dapat dikaitkan dengan tingkat minimal dan ukuran variable yang diukur seperti jumlah lembaga fisik sebagai titik akses dan pinjaman kepada UMKM (kedalaman keuangan) (Bernadett V. Operaña, 2016).

\subsection{Inkulasi Keuangan dan Non Performing Loan (NPL)}

Penelitian ini akan menggunakan total pinjaman kepada sektor UMKM sebagai indikator inkluasi keuangan. UMKM mewakili perusahaan yang fokus pada kebijakan dan program inkluasi keuangan di Indonesia. Keuangan mikro memainkan peran penting dalam mempromosikan keuangan inklusif karena sebagian besar rumah tangga di Negara-negara miskin dan berpenghasilan rendah terlibat dalam kegiatan usaha kecil. Dalam sebuah studi, sektor UMKM di 99 negara, menunjukan bahwa UKM memperkerjakan sebagian besar pekerja di Negara berkembang yang 
terhitung sekitar 50\% karyawan di Negara berkembang (Ayyagari, Demirgux-Kunt dan Maksimovic, 2011). Penelitian lain tentang efek keuangan mikro menunjukan efek positif pada konsumsi, kemandirian ekonomi dan beberapa aspek kesehatan mental dan kesejahteraan (WB, 2014). Indikator stabilitas keuangan menggunakan Financial Soudness Index yakni Gross Domestic Product (GDP) dan Non Peforming Loan (NPL).

Pinjaman berupa kredit (kualitas asset) adalah asset uatama bank komersial dan merupakan sumber penghasilan terbesar. Kualitas portofolio kredit menentukan profitabilitas bank (Ongoro \& Kusa, 2013). Risiko tertinggi yang dihadapi bank adalah kerugian yang berasal dari pinjaman macet. Delis et al (2014) mengamati bahwa rasio NPL adalah yang terbaik untuk mengukur eksposur risiko kredit. Perhatian utama dari semua bank komersial adalah mempertahankan jumlah NPL agar tetap rendah karena ini menunjukan kesehatan yang baik dari portofolio bank dan tingkat NPL yang tinggi mempengaruhi profitabilitas secara negatif.

Peningkatan akses keuangan melalui inkluasi keuangan mengubah komposisi pelanggan dalam hal perilaku menabung dan meminjam. Perubahan kompoisis ini dapat mendukung stabilitas keuangan melalui diversifikasi risiko (Hannings \& Jansen, 2010). Namun, jika inklusi keuangan diperluas ke daerah dan klien yang tidak kredibel maka ini akan menimbulkan peningkatan risiko kredit dan menjadi ancaman bagi stabilitas. Mohrotra dan Yetman, 2014 mengamati bahwa stabilitas keuangan dapat meningkatkan kepercayaan dalam system keuangan dan karena itu meningkatkan inkluasi keuangan. Sebaliknya, penekanan yang berlebihan pada stabilitas keuangan dapat memperkecil inkluasi keuangan. Terutama pada saat terjadi pengetatan kebijakan untuk meningkatkan keuntungan dan memotong dari segmen risiko.

\subsection{Inklusi Keuangan dan Produk Domestik Bruto}

Indikator yang kedua adalah Produk Domestik Bruto (PDB)/Gross Domestic Product (GDP). Kondisi makro ekonomi yang baik diharapkan dapat meningkatkan inkluasi keuangan. Lebih tinggi pendapatan memungkinkan tingkat tabungan yang lebih tinggi yang pada gilirannya kemungkinan akan meningkatkan jumlah rekening tabungan (Adusei, 2015). Penelitian ini akan menggunakan variable PDB untuk merepresentasikan perkembangan ekonomi dan sikluas bisnis ekonomi di Indonesia serta menganalisis implikasi inkluasi keuangan pada stabilitas bank. Honohan (2008) mengamati bahwa pembangunan ekonomi umumnya bertepatan dengan peningkatan inkluasi keuangan dan karenannya akan menarik apakah dampak inkluasi keuangan tetap signifikan terhadap PDB.

Kosmidou (2008) menemukan bahwa pertumbuhan PDB meningkatkan profitabilitas yang pada gilirannya meningkatkan stabilitas. Ini berhubungan dengan fakta bahwa peningkatan PDB 
dikaitkan dengan peningkatan secara umum dalam pendapatan dalam suatu perekonomian dan karenannya peningkatan inklusi keuangan. Namun Tan dan Floros (2012) mengamati bahwa pertumbuhan PDB dapat mengarah pada penurunan profitabilitas yang secara langsung mempengaruhi stabilitas secara negatif. Hal ini disebabkan karena peningkatan pertumbuhan ekonomi mengarah ke lingkungan yang kondusif dan menurunkan penghalang masuk ke bank dan karenanya peningkatan persaingan. Meningkatnya persaingan di sektor perbankan juga mengurangi profitabilitas perbankan menyiratkan pengurangan stabilitas. Dari penelitian sebelumnya jelas bahwa pengaruh PDB terhadap inklusi keuangan dan stabilitas bank tidak dapat disimpulkan.

Dengan latar belakang inilah penelitian ini berusaha untuk menganalisisi dampak inkluasi keuangan terhadap risiko kredit bank komersial di Indonesia. Selain itu, juga diteliti efek moderasi dari laju pertumbuhan PDB pada hubungan antara inklusi keuangan dan risiko kredit bank di Indonesia.

\section{METODE PENELITIAN}

Data inkluasi keuangan yang digunakan untuk menggambarkan tingkat inkluasi bersumber dari keuangan bersumber dari laporan triwulan Strategi Nasional Keuangan Inklusif (SNKI), data stabilitas keuangan perbankan diperoleh dari laporan tahunan Otoritas Jasa Keuangan dari periode tahun serta data pertumbuhan produk domestik bruto dari laporan Bank Dunia (World Bank).

Dalam penelitian ini akan menggunakan analisis multivariate. Analisis multivariate digunakan untuk melakukan regresi pada hubungan antara berbagai variable bebas terhadap variable terikat. Untuk menentukan hubungan antara inkluasi keuangan dan stabilitas keuangan, penelitian ini akan menggunakan data bulanan untuk periode tahun 2002-2017. Indikator untuk inkluasi keuangan (a) jumlah kantor bank, (b) pinjaman kepada UMKM (CMSME), sedangkan untuk indikator stabilitas keuangan menggunakan Credit Risk yakni rasio Non Performing Loan (NPL) dan Produk Domestik Bruto (PDB). Model empiris umum yang digunakan dalam penelitian ini diadaptasi dari Mostak dan Sushanta (2015P dan Beck et al (2009).

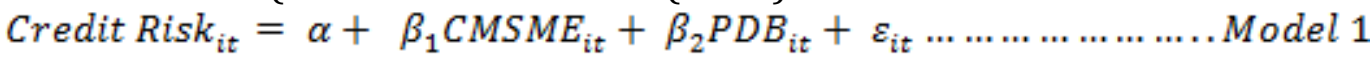

$$
\begin{aligned}
& \text { Credit Risk }_{i t}=\alpha+\beta_{1} C M S M E_{i t}+\beta_{2} P D B_{i t}+\beta_{3}\left(C M S M E X P D B_{i t}\right) \\
& +\varepsilon_{i t} \ldots \text { Model } 2
\end{aligned}
$$

\section{HASIL DAN PEMBAHASAN}

\section{Trend Inklusi Keuangan dan Stabilitas Keuangan}

Perbandingan sederhana dari hubungan antara pertumbuhan inklusi keuangan dan stabilitas keuangan di Indonesia. Pertumbuhan inklusi salah satunya adalah akses dengan indikator jumlah kantor bank yang tersedia 
dalam melayani masyarakat dengan rasio NPL sebagai indikator stabilitas keuangan periode tahun 2007-2017.

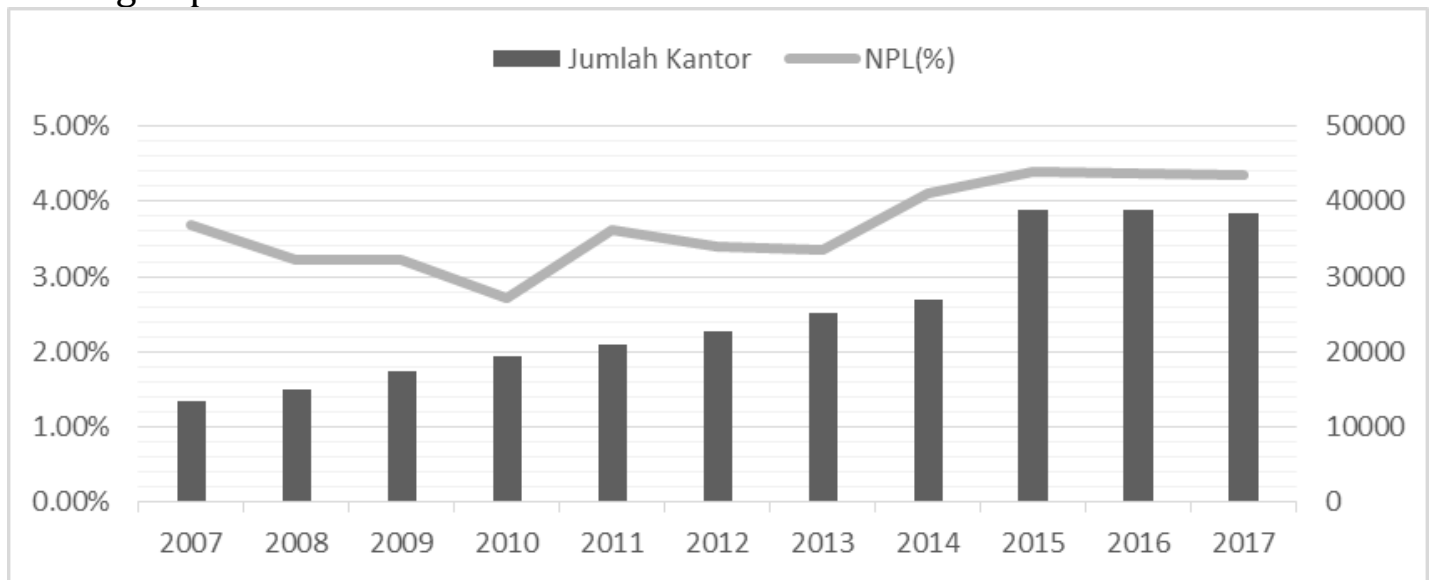

\section{Gambar 3: Jumlah Kantor Pelayanan Bank dan Kinerja NPL Perbankan di Indonesia periode tahun 2007-2017.}

Dari Gambar 3 dapat diketahui bahwa trend selama periode tahun 2007-2017 mengalami fluktuasi. Pada periode pertama tahun 2007-2013 jumlah kantor pelayanan bank mengalami peningkatan dan disisi lain secara umum terjadi penurunan jumlah kredit bermasalah (Non Performing Loan). Ketika bank meningkatkan jaringan cabang mereka, kredit menjadi tersedia dan menjangkau pasar baru yang sebelumnya kurang terlayani dan tidak memiliki rekening bank seperti yang terlihat pada Gambar 4. Penambahan institusi fisik berkontribusi pada kebijakan efisien biaya bank, sehingga bank cenderung efisien dalam mengelola kredit mereka sehingga menurunkan rasio NPL secara umum. Kemudian di periode kedua tahun 2014-2017 peningkatan jumlah kantor layanan berbanding lurus dengan peningkatan jumlah kredit UMKM dan peningkatan rasio NPL, hal ini bisa terjadi karena faktor risiko kredit yang terjadi akibat kegagalan pembayaran dari nasabah dan faktor makroekonomi lainnya.

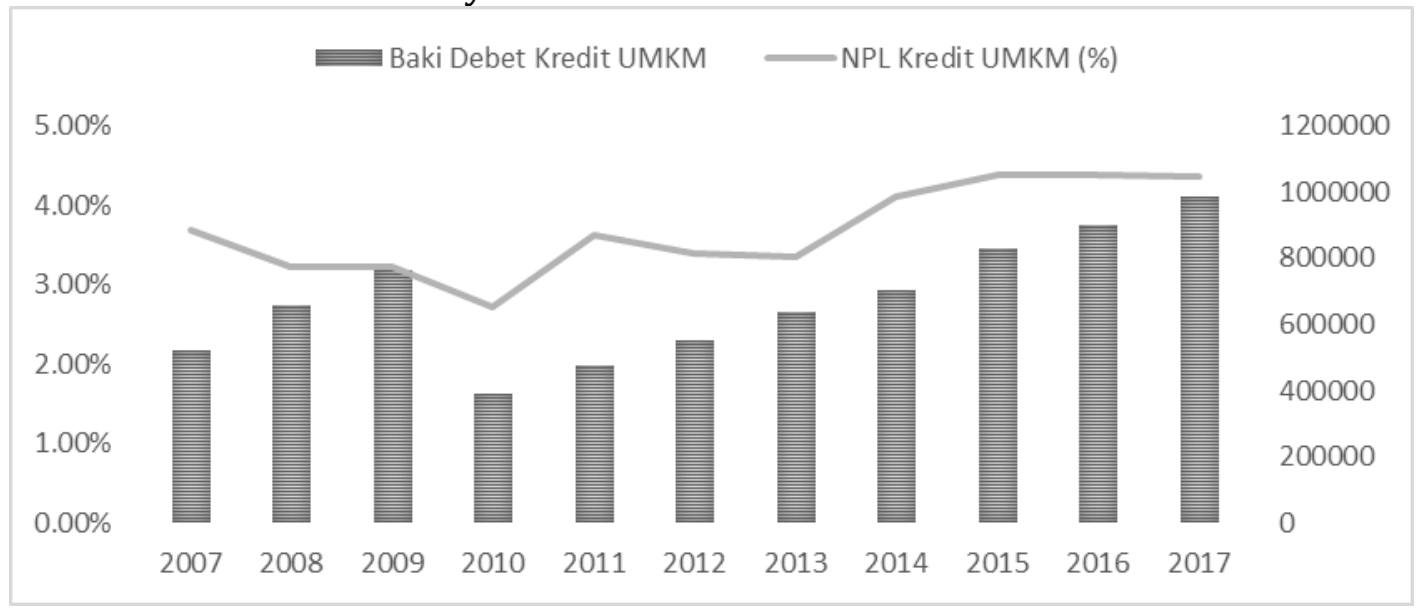




\section{Gambar 4: Baki debet kredit UMKM dan NPL Kredit UMKM di Indonesia periode tahun 2007-2017.}

\section{Pertumbuhan Produk Domestik Bruto}

Pertumbuhan ekonomi di Indonesia menunjukan pertumbuhan dilihat dari meningkatkan pertumbuhan produk domestik bruto selama periode tahun 2007-2017. Pencapaian target pertumbuhan ekonomi setiap tahun didukung oleh kinerja pertumbuhan ekonomi domestic yang relatif stabil. Selain itu lingkungan perekonomian global mulai tumbuh dan terjaga risiko tiap tahun. Pemerintah Indonesia mendorong dan memperkuat seluruh sumber pertumbuhan yakni konsumsi rumah tangga, investasi, ekspor maupun belanja pemerintah yang lebih produktif dan efisien.

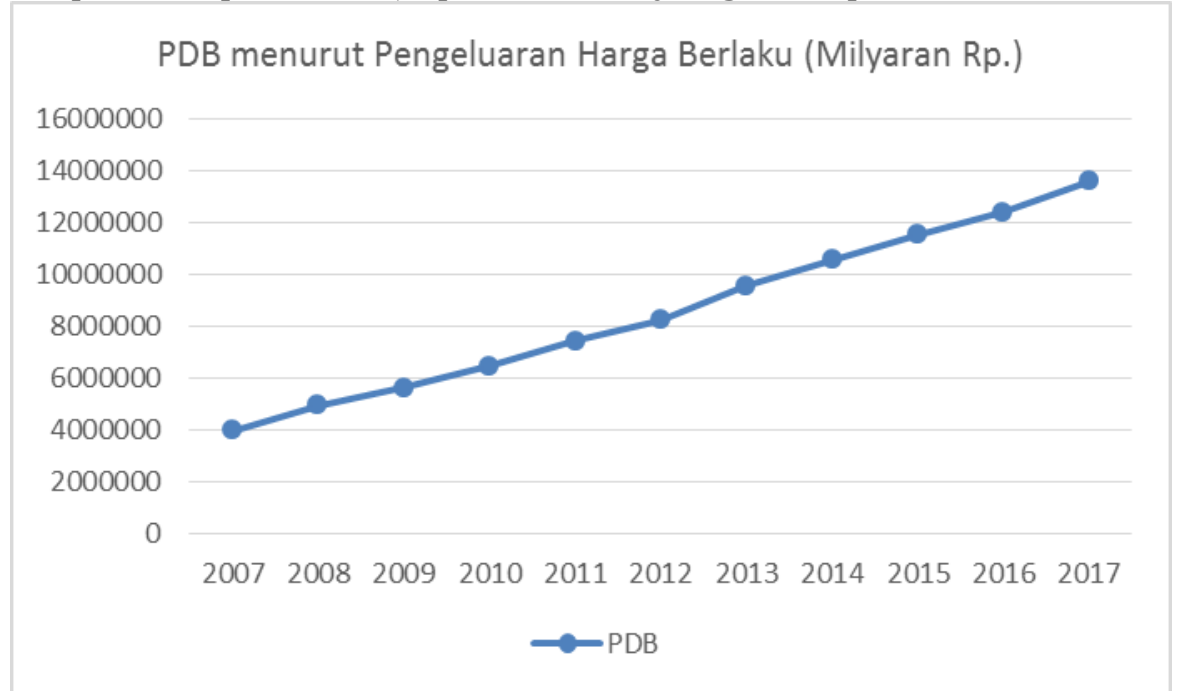

Gambar 5: Pertumbun PDB Indonesia Periode Tahun 2007-2017

\section{Model dan Hasil Pembahasan}

Penelitian ini melakukan uji statistik yakni uji asumsi dan regresi. Statistik yang digunakan termasuk uji normalitas, heteroskedastisitas multikilnieritas dan autokorelasi. Tes ini dilakukan untuk memastikan bahwa analisis statistik yang dilakukan berpegang pada asumsi regresi sehingga menghindari temuan yang bias.

\subsection{Uji Normalitas}

Uji normalitas dilakukan dengan menggunakan Jarque-Bera (JB) dan grafik normalitas. Hasil pada gambar menunjukan bahwa residu terdistribusi normal. Untuk menetapkan lebih lanjut distribusi normal, penelitian ini mengadopsi tes Jarque-Bera yang merupakan tes yang lebih meyakinkan daripada pemeriksaan grafis untuk menguji normalitas. Hasil uji Jarque-Bera ditunjukan pada tabel dibawah ini:

\section{Tabel 1. Uji Normalitas}




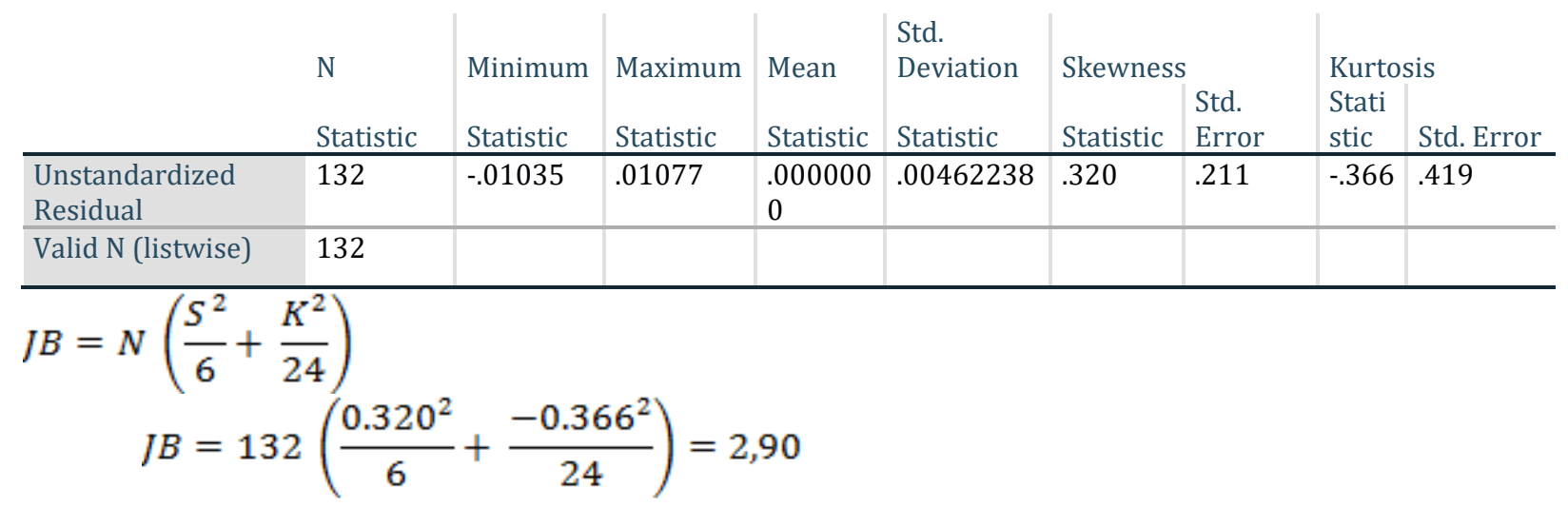

Normal P-P Plot of Regression Standardized Residual

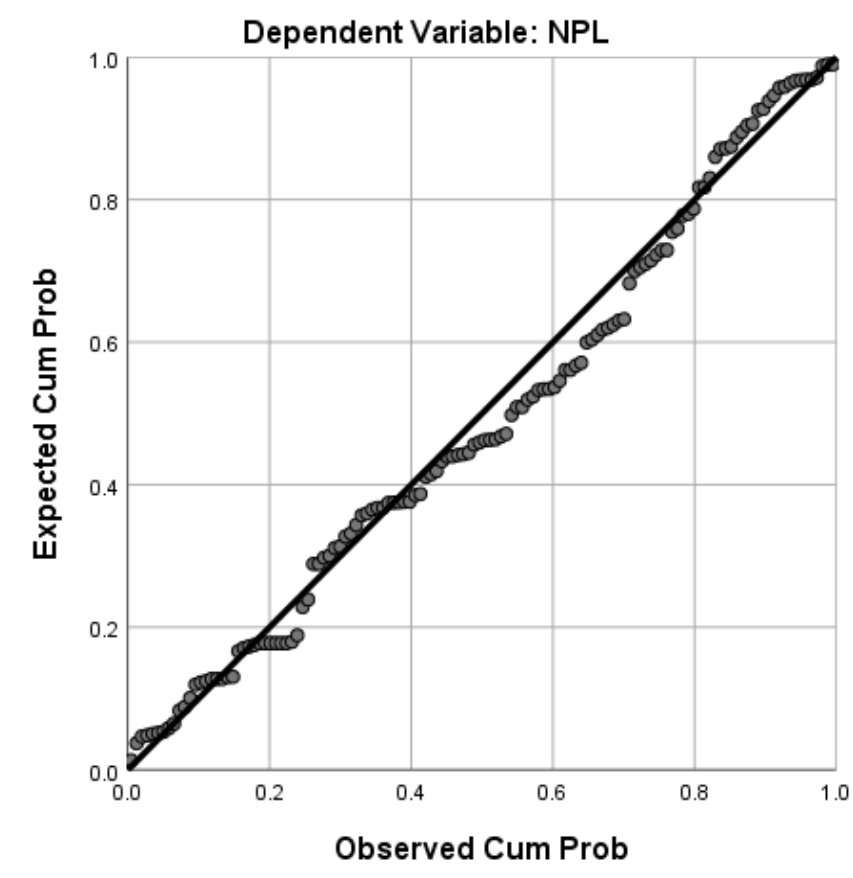

Gambar 6. Uji Normalitas

Bila tingkat signifikasi yang dipilih dalam penelitian adalah $5 \%$, maka nilai Chi Kuadrat dengan $\mathrm{df}=2$ adalah sebesar 5,99. Nilai JB lebih kecil dari 5,99, maka tidak terdapat masalah normalitas residu pada datadata penelitian ini.

\subsection{Uji Heteroskedastisitas}

Penelitian selanjutnya melakukan uji heteroskedastisitas untuk menguji asumsi bahwa residual memiliki varians konstan. Metode scatter plots regresi digunakan dalam penelitian karena lebih praktis. Hasil pengujian memperlihatkan bahwa titik-titik atau plot menyebar tidak beraturan diatas dan dibawah sumbu 0 pada sumbu Y. maka dapat disimpulkan bahwa tidak terdapat gejala heteroskedastisitas. Hasilnya adalah sebagai berikut: 


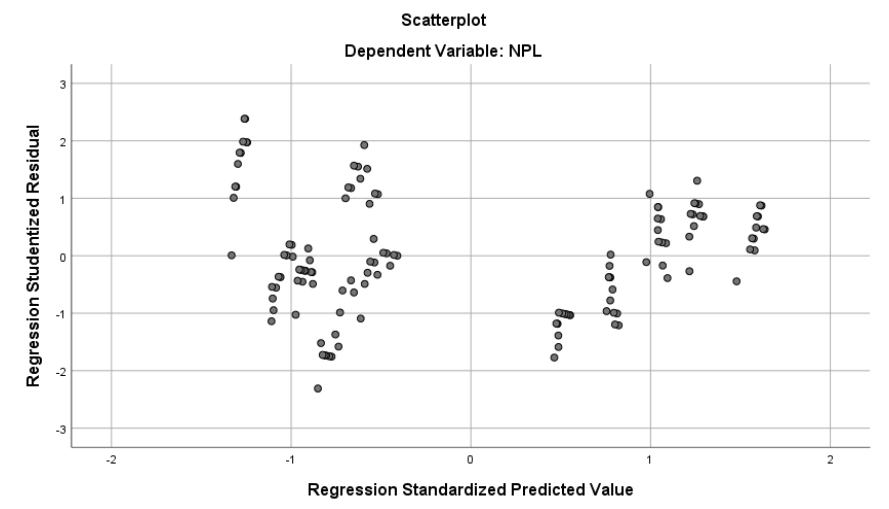

Gambar 7. Uji Heteroskedastisitas

\subsection{Uji Multikolinieritas}

Pengujian multikolinieritas dalam penelitian ini menggunakan VIF. Penelitian ini mengadopsi aturan prkatis untuk nilai VIF 10 sebagai ambang batas. Nilai VIF lebih besar dari 10 menunjukan adanya multikolinearitas begitu juga sebaliknya.

\section{Tabel 2. Uji Multikolinieritas}

\begin{tabular}{|c|c|c|c|c|c|c|c|c|}
\hline \multirow[b]{2}{*}{ Model } & & \multicolumn{2}{|c|}{$\begin{array}{l}\text { Unstandardized } \\
\text { Coefficients }\end{array}$} & \multirow{2}{*}{$\begin{array}{l}\text { Standardized } \\
\text { Coefficients } \\
\text { Beta }\end{array}$} & \multirow[b]{2}{*}{$\mathrm{t}$} & \multirow[b]{2}{*}{ Sig. } & \multicolumn{2}{|c|}{ Collinearity Statistics } \\
\hline & & $\mathrm{B}$ & Std. Error & & & & Tolerance & VIF \\
\hline 1 & (Constant) & .034 & .002 & & 19.043 & .000 & & \\
\hline & Kredit UMKM & $-2.733 E-9$ & .000 & -.106 & -1.378 & .171 & .917 & 1.091 \\
\hline & PDB & $1.336 \mathrm{E}-8$ & .000 & .571 & 7.428 & .000 & .917 & 1.091 \\
\hline
\end{tabular}

a. Dependent Variable: NPL

Nilai VIF pada table diatas keduanya dibawah 10 dan atau nilai Tolerance lebih dari 0,1 maka dapat disimpulkan dengan tegas bahwa tidak terdapat masalah multikolinieritas.

\subsection{Hasil Uji Regresi Berganda}

\section{Tabel 3. Pertumbuhan PDB sebagai Variabel Bebas}

\begin{tabular}{|c|c|c|c|c|c|c|}
\hline \multirow[b]{2}{*}{ Model } & & \multicolumn{2}{|c|}{ Unstandardized Coefficients } & \multirow{2}{*}{$\begin{array}{l}\text { Standardized } \\
\text { Coefficients } \\
\text { Beta }\end{array}$} & \multirow[b]{2}{*}{$\mathrm{t}$} & \multirow[b]{2}{*}{ Sig. } \\
\hline & & $\mathrm{B}$ & Std. Error & & & \\
\hline 1 & (Constant) & .034 & .002 & & 19.043 & .000 \\
\hline & Kredit UMKM & $-2.733 E-9$ & .000 & -.106 & -1.378 & .171 \\
\hline & PDB & $1.336 \mathrm{E}-8$ & .000 & .571 & 7.428 & .000 \\
\hline
\end{tabular}

a. Dependent Variable: NPL 


\begin{tabular}{ll|l|l|l|l} 
Model & $\mathrm{R}$ & R Square & $\begin{array}{l}\text { Adjusted } \\
\text { Square }\end{array}$ & $\mathrm{R}$ & $\begin{array}{l}\text { Std. Error of the } \\
\text { Estimate }\end{array}$ \\
\hline 1 & $.550^{\mathrm{a}}$ & .302 & .291 & .0050407 \\
\hline a. Predictors: (Constant), PDB, Kredit UMKM
\end{tabular}

Berdasarkan hasil pada Tabel 3 menunjukan R kuadrat sebesar 0,302. Ini menyiratkan bahwa inklusi keuangan melalui pertumbuhan kredit UMKM dan tingkat pertumbuhan PDB memiliki pengaruh hanya sebesar 30,2\% dari stabilitas keuangan (NPL) perbankan di Indonesia. Nilai statistic F adalah 0,000 yang kurang dari 0,05. Hal ini menunjukan bahwa inkluasi keuangan dan tingkat pertumbuhan PDB secara bersama-sama signifikan dalam mempengaruhi stabilitas keuangan perbankan di Indonesia. Koefisien Kredit UMKM ( $\beta=-2.733$, Sig. 0.171, > 0,05\%) menunjukan hubungan yang negatif tidak signifikan terhadap Non Performing Loan (NPL) perbankan di Indonesia. Hal ini berarti bahwa peningkatan kredit UMKM akan menyebabkan penurunan NPL perbankan di Indonesia secara tidak signifikan. Koefisien laju pertumbuhan PDB pada $((\beta=1,336$, Sig. 0.000 , < $0,05 \%)$ menunjukan hubungan positif dan signifikan terhadap NPL perbankan di Indonesia. Peningkatan pertumbuhan PDB akan menyebabkan peningkatan risiko kredit (NPL) pada perbankan di Indonesia. Maka persamaan untk Model 1 adalah sebagai berikut:

$$
Y_{N P L}=0,034-2,733 \mathrm{Kr} U M \mathrm{KM}_{i t}+1,336 P D B_{i t}+\varepsilon_{i t}
$$

Langkah kedua, variable pertumbuhan PDB dijadikan variable moderator. Hasil analisis regresi adalah sebegai berikut:

Tabel 4. Pertumbuhan PDB sebagai Variabel Moderator

\begin{tabular}{|c|c|c|c|c|c|c|}
\hline \multirow[b]{2}{*}{ Model } & & \multicolumn{2}{|c|}{ Unstandardized Coefficients } & \multirow{2}{*}{$\begin{array}{l}\text { Standardized } \\
\text { Coefficients } \\
\text { Beta }\end{array}$} & \multirow[b]{2}{*}{$\mathrm{t}$} & \multirow[b]{2}{*}{ Sig. } \\
\hline & & $\mathrm{B}$ & Std. Error & & & \\
\hline \multirow[t]{3}{*}{1} & (Constant) & .042 & .001 & & 28.585 & .000 \\
\hline & Kredit UMKM & $-1.589 \mathrm{E}-8$ & .000 & -.616 & -6.198 & .000 \\
\hline & Moderating & $1.999 \mathrm{E}-14$ & .000 & .925 & 9.310 & .000 \\
\hline
\end{tabular}

a. Dependent Variable: NPL

\begin{tabular}{|c|c|c|c|c|}
\hline Model & $\mathrm{R}$ & R Square & $\begin{array}{l}\text { Adjusted } \quad \mathrm{R} \\
\text { Square }\end{array}$ & $\begin{array}{l}\text { Std. Error of the } \\
\text { Estimate }\end{array}$ \\
\hline 1 & $.636^{\mathrm{a}}$ & .404 & .395 & .0046581 \\
\hline
\end{tabular}

Berdasarkan Tabel 4 diketahui bahwa R kuadrat sebesar 0,404. Ini menyiratkan bahwa ketika tingkat pertumbuhan PDB diposisikan sebagai moderator, model ini memiliki kekuatan penjelas sebesar 40,4\% terhadap stabilitas keuangan (NPL) perbankan di Indonesia. Nilai statistik F adalah sebesar 43,76 dengan nilai Sig sebesar 0,000 yang kurang dari 0,05. Hal ini menunjukan bahwa inkluasi keuangan dan tingkat pertumbuhan PDB sebagai moderator secara bersama-sama signifikan dalam mempengaruhi stabilitas keuangan perbankan di Indonesia. Koefisien inklusi keuangan $(\beta=$ 
1,589, Sig. $0.000,<0,05)$ menunjukan hubungan yang signifikan secara statistic antara inklusi keuangan dan stabilitas perbankan di Indonesia. Koefisien regresi $-1,589$ yang diperoleh dalam penelitian ini menunjukan bahwa peningkatan pertumbuhan kredit UMKM akan menyebabkan 1,589 penurunan kredit bermasalah (NPL). Koefisien laju pertumbuhan PDB ( $\beta=-$ $1,999$, Sig. $0.000,<0,05)$ menunjukan hubungan yang signifikan secara statistik antara tingkat pertumbuhan PDB dan stabilitas keuangan (NPL) perbankan di Indonesia. Ini menunjukan bahwa tingkat pertumbuhan PDB secara langsung mempengaruhi stabilitas keuangan keuangan (NPL) dan dapat memoderasi hubungan antara inkluasi keuangan (Kredit UMKM) dan Stabilitas Keuangan (NPL). Ini berarti bahwa tingkat pertumbuhan PDB memperkuat pengaruh antara inklusi keuangan (kredit UMKM) terhadap stabilitas keuangan (NPL) perbankan di Indonesia.

\section{KESIMPULAN, IMPLIKASI DAN KETERBATASAN PENELITIAN}

Penelitian ini bertujuan untuk menguji pengaruh inklusi keuangan terhadap stabilitas keuangan perbankan di Indonesia. Panel data yang digunakan dalam penelitian selama periode tahun 2007-2017 dan dianalisis dengan multiple regresi. Untuk mencapai tujuan tersebut, variable inklusi keuangan menggunakan indikator pertumbuhan kredit UMKM, sedangkan variable dependen stabilitas keuangan perbankan menggunakan indikator tingkat rasio kredit bermasalah (NPL).

Studi ini menganalisis tren dalam inkluasi keuangan termasuk pertumbuhan kredit UMKM merupakan indikasi yang menjelaskan dari peningkatan aksesbilitas bank oleh masyarakat pelaku UKM. Indikator stabilitas keuangan perbankan menunjukan eksposur kredit selama periode tahun 20072013 secara konstan, namun pada tahun 2014 eksposur terhadap risiko kredit meningkat akibat dari kondisi perekonomian global yang berimbas pada perekonomian di Indonesia. Penelitian lebih lanjut menggunakan regresi berganda untuk memastikan hubungan antara inkluasi keuangan dan pertumbuhan tingkat PDB terhadap risiko kredit bermasalah yang merupakan variable dependent dalam penelitian ini. Hasil penelitian menunjukan bahwa pertumbuhan kredit UMKM memiliki pengaruh negatif terhadap risiko kredit yang dikaitkan dengan stabilitas yang lebih baik. Peningkatan jumlah kredit UMKM dan disisi lain secara umum terjadi penurunan jumlah kredit bermasalah (Non Performing Loan) terjadi karena kredit mampu menjangkau pasar baru yang sebelumnya kurang terlayani.

Peningkatan rasio kredit berkontribusi pada kebijakan efisien biaya bank, sehingga bank cenderung efisien dalam mengelola kredit mereka sehingga menurunkan rasio NPL secara umum. Tingkat kredit sektor UMKM rata-rata selama periode 2007-2017 berada diangka 45-50\% dari total kredit perbankan secara keseluruhan, dan kinerja NPL sektor UMKM rata-rata sebesar 2,75-3,5\% lebih rendah bila dibandingkan dengan NPL kredit sektor non-UMKM rata-rata sebesar 4,5 - 6\%. Tingkat pertumbuhan PDB secara positif dan signifikan 
berpengaruh langsung terhadap stabilitas keuangan (NPL) perbankan di Indonesia. Sekaligus secara signifikan berpengaruh kuat sebagai variable moderator hubungan antara inklusi keuangan dan stabilitas keuangan perbankan di Indonesia.

Rekomendasi berdasarkan hasil penelitian ini adalah perbankan di Indonesia harus mencari cara untuk meningkatkan tingkat inklusi keuangan dengan memperluas pada dimensi penetrasi seperti ketersediaan kantor layanan bank, aksesbilitas bank dan penggunaan bank dengan menggunakan saluran yang mudah diterima oleh semua masyarakat dan produk yang mudah dimengerti untuk meningkatkan penggunaan. Studi ini juga merekomendasikan kepada perbankan di Indonesia untuk merumuskan strategi dalam mengatasi fundamental ekonomi makro khususnya PDB, yang mempengaruhi tingkat inklusi keuangan dan risiko kredit. Lembaga keuangan formal harus memfasilitasi kelompok masyarakat berpenghasilan rendah untuk mengakses layanan keuangan. Sebelumnya pemerintah dapat mempertimbangkan menyediakan literasi keuangan diantara penduduk untuk memungkinkan mereka memanfaatkan layanan keuangan untuk kesejahteraan masyarakat.

Keterbatasan penelitian ini terletak pada variable penelitian yang terbatas. Penelitian selanjutnya bisa menggunakan variabel non rasio keuangan seperti ketersediaan kantor layanan bank, kepemilikian rekening bank, penggunaan system perbankan online dalam mengukur tingkat inklusi keuangan.

\section{REFRENSI}

Adusei, M., \& Elliott, C. (2015). The impact of bank size and funding risk on bank stability in Ghana. Cogent Economics \& Finance, 3(1), 1111489. https://doi.org/10.1080/23322039.2015.1111489

Allen, F., Carletti, E., Cull, R., Qian, J., Senbet, L.W., \& Valenzuela, P. (2013). Improving access to banking: Evidence from Kenya. World Bank Policy Research Working Paper No. 6593. https://doi.org/10.1596/1813-9450-6593

Ayyagari, Meghana and Thorsten Beck. 2015. Financial Inclusion in Asia: An Overview. ADB Economics Working Paper Series No. 449, Manila, Philippines.

Beck, Thorsten, Asli Demirguc-Kunt and Ross Levine. 2005. SMEs, Growth, And Poverty: Cross-Country Evidence. National Bureau of Economic Research Working Paper No. 11224, Cambridge, MA

Beck, T., De Jonghe, O., \& Schepens, G. (2013). Bank competition and stability: Crosscountry heterogeneity. J. Finance. Intermed. 22, 218-244. https://doi.org/10.1016/j.jfi.2012.07.001

Carneiro, F. L. (2011). Is there evidence of a trade-off between financial stability and efficiency of financial intermediation? Preliminary insights from the global financial crisis of 2007-2009. Retrieved from https://programs.wcfia.harvard.edu/files/fellows/files/carneiro.pdf

Giné, Xavier, Pamela Jakiela, Dean Karlan, and Jonathan Morduch. 2009. Microfinance Games. Financial Access Initiatives. New York, NY. 
Hannig, A., \& Jansen, S. (2010). Financial inclusion and financial stability: Current policy issues. $\quad$ Retrieved https://www.adb.org/sites/default/files/publication/156114/adbi-wp259.pdf

Morgan, P., \& Pontines, V. (2014). Financial Stability and Financial Inclusion. Asian Development Bank Institute. ADBI Working Paper 488. https://doi.org/10.2139/ssrn.2464018

Mostak, M., \& Sushanta, M. (2015). Is financial inclusion good for bank stability? International evidence. University of London, U.K. Retrieved from https://editorialexpress.com/cgibin/conference/download.cgi?db_name...paper

Ongore, V. O., \& Kusa, G. B. (2013). Determinants of Financial performance of commercial banks in Kenya. International Journal of Economics and Financial Issues, 237-238.

Strategi Nasional Keuangan Inklusif. Statistik Sistem Keuangan Indonesia Desember 2017.

https://drive.google.com/file/d/1IuyNPJxiviEX8rHLVUxo_0tXD3n8SmE0/view. . Statistik Sistem Keuangan Indonesia Desember 2016. https://drive.google.com/file/d/1QJGdkB357-Vf90JVlnm10buGpSt0hq08/view - Memacu Pertumbuhan Ekonomi Melalui Sektor Jasa Keuangan yang Kontributif, Stabil dan Inklusif. Annual Report 2015. https://drive.google.com/file/d/1hXjkmKiwWWz3H05jDgxJeCTo791VhP_s/view .Memperkuat Fundamental Perekonomian Melalui Inklusi Keuangan. Annual Report 2014. https://drive.google.com/file/d/1BQyfQ6NPwxrNEseTWZkmbQMLTpClSr0/view

Bank Indonesia. https://www.bi.go.id/id/umkm/kredit/data/Default.aspx

https://www.bi.go.id/id/perbankan/ssk/ikhtisar/definisi/Contents/Default.aspx Otoritas Jasa Keuangan. https://www.ojk.go.id/id/kanal/perbankan/data-danstatistik/statistik-perbankan-indonesia/Default.aspx

World Bank. 2018. Global Financial Development Report. Financial Inclusion. http://www.worldbank.org/en/publication/gfdr

http://databank.worldbank.org/data/home.aspx

https://www.imf.org/external/pubs/ft/wp 